\title{
Subsistence Needs and Individual Duties
}

\begin{abstract}
Various human rights documents list the human right to an adequate standard of living. While the content of the duties of States and non-State actors are being made increasingly clear, the duties we have as individuals with regard to this human right are left nearly completely undefined. This article therefore wishes to clarify, firstly which duties towards the global poor we have as individuals and, secondly, what the status of these duties is. I will argue that nearly all our duties that stem from global subsistence needs are at present duties of virtue. I will arrive at this conclusion in two steps. Section I will aim to provide an exhaustive overview of our individual duties related to global subsistence needs. Next, Section II will need to ascertain the status of each of these duties. Accordingly, it will first have to offer definitions of the distinction between perfect and imperfect duties, and of the difference between duties of justice and duties of virtue. Subsequently, these definitions will be applied to the duties presented in Section I. Finally, I will conclude with a brief reflection on the significance of virtue as a necessary complement to justice.
\end{abstract}

KEYWORDS: Human rights; individual duties; global poverty; subsistence needs; virtue; perfect and imperfect duties.

Eric R. Boot

Faculty of Law

Radbound University Nijmegen

\section{Introduction}

It is one thing to provide a declaration of human rights; it is quite another to clarify and allocate the duties to which these rights give rise. The latter task is especially formidable in the case of subsistence rights, which will be under discussion here. Both the Universal Declaration of Human Rights (UDHR) and the International Covenant on Economic, Social and Cultural Rights recognize such rights as human rights under the name of a human right to an adequate standard of living (Article 25 and Article 11 respectively). Human rights law has taken considerable steps forward in defining the content and scope of State duties to prevent and alleviate poverty. The duties of non-State actors are discussed less and in a vaguer fashion, but human rights law has begun to rectify this oversight. ${ }^{1}$ Yet when it comes to the duties of individuals, a crushing silence reigns. Nowhere in the various covenants and declarations on human rights, the General Comments of the Committee on Economic, Social and Cultural Rights (CESCR), or in the work of human rights scholars, are we provided an adequate treatment of the duties of individuals that spring from this right. Individual duties are offered perfunctory mention at best. Thus the CESCR, for example, in its General Comments which are meant to elucidate the rights listed in the Covenant and allocate the corresponding duties simply mentions that all members of society (including individuals) "have responsibilities in the realization of the right to food, ${ }^{2}$ but leaves the question of the exact content and status of these "responsibilities" wide open. In short, if we wish to know which duties we individuals have as a 
consequence of Article 25 UDHR, we will not find any answers in human rights documents or in the General Comments of the CESCR. Are we to conclude that therefore individuals have no real duties regarding the right to an adequate standard of living?

Not wishing to answer this question in a positive fashion, I will undertake an examination of our individual duties concerning the fulfillment of global subsistence needs. This will involve treating and answering questions such as the following: Why do we have duties to the global poor in the first place? Are our individual duties to help the global poor positive or only negative? Are these best understood as duties of virtue or as duties of justice (claimable by right-holders and enforceable by legal means)? Are these strict, perfect duties, or wide, imperfect duties? The position I will defend is that most of our duties that stem from subsistence needs, prior to the creation of institutions that can pair specific right-holders to specific duty-bearers, are necessarily duties of virtue.

I will arrive at this conclusion in two steps. Section I will be centered on the question "Who has what duties in fulfilling subsistence needs?". Are our duties limited to refraining from causing harm and offering compensation when actual harm is done, or ought we to lend a helping hand whenever it is in our power to do so? The goal of this first section will be to provide an exhaustive overview of our individual duties related to global subsistence needs. Next, Section II will need to ascertain the status of each of these duties. Accordingly, it will first have to offer definitions of the distinction between perfect and imperfect duties, and of the difference between duties of justice and duties of virtue. Subsequently, these definitions will be applied to the duties presented in Section I. Finally, I will conclude with a brief reflection on the significance of (duties of) virtue as a necessary complement to (duties of) justice.

\section{Who has what duties in fulfilling subsistence needs?}

In this subsection I wish to provide an overview of our individual duties regarding global subsistence needs. Hereby I will clarify which causes of poverty lead to which duties for whom. The status of these duties will then be determined in the next section. In order to arrive at such an overview, I will discuss several theories of such duties, most notably Peter Singer's interactionist approach, which is focused solely on remedial responsibility, and Thomas Pogge's institutional approach, which focuses solely on outcome responsibility.

The only incontrovertible duty we have, on which all authors agree, is the negative duty to refrain from interfering directly with the ability of others to meet their own subsistence needs. If one's actions directly harm this ability, then we incur positive obligations ${ }^{4}$ to remedy the loss we have caused. This is a case in which duties can be assigned by relying on what David Miller has termed outcome responsibility. ${ }^{5}$ This approach to responsibility typically holds that our duties are limited to refrain from causing harm and suffering, though they may involve positive obligations as well in the case one has violated one's original duty of forbearance.

Restricting the scope of our duties to negative duties of forbearance, however, seems rather limited. For this reason, certain authors have made the case for positive duties of aid by relying on remedial responsibility: our individual duties regarding subsistence needs are not limited to mere forbearance, but instead we have a duty to alleviate suffering whenever it is within our means to do so. ${ }^{6}$ Perhaps the best-known example of remedial responsibility can be found in the work of Peter Singer. In Famine, Affluence, and Morality he develops his central moral principle: "if it is in our power to prevent something bad from happening, without thereby sacrificing anything of comparable moral importance, we ought, morally, to do it." ${ }^{\text {, }}$ He subsequently illustrates the validity of this principle by applying it to a 
concrete case. If I happen to walk by a shallow pond, in which I spot a drowning child, I ought to go into the pond and rescue the child. It is, after all, in my power to prevent something bad (the child drowning) from happening and the costs (getting my clothes wet, perhaps catching a cold) by no means qualify as "anything of comparable moral importance." We can therefore readily arrive at the conclusion that I ought to rescue the child. If we accept this principle in the case of the drowning child, Singer continues, we can also apply it to the problem of global poverty. The citizens of wealthy nations could save many lives threatened by poverty worldwide by contributing money, and doing so would not require the sacrifice of anything equally morally important compared to the value of being free from poverty. Yet, how much ought we to give? Singer replies that "we ought to give until we reach the level of marginal utility - that is, the level at which, by giving more, I would cause as much suffering to myself or my dependents as I would relieve by my gifts." Anticipating the criticism that this duty would be too demanding, Singer formulates a more moderate version (though he believes the strong account to be correct): "We should prevent bad occurrences unless, to do so, we had to sacrifice something morally significant." ${ }^{9}$ In this version, it is not necessary for us to give until we reach the level of marginal utility, for reducing oneself and one's dependents to that level may be viewed as sacrificing something morally significant.

The utilitarian basis of this argument is clear: "We ought to be preventing as much suffering as we can without sacrificing something else of comparable moral importance." ${ }^{\prime 10}$ Note that it is hereby irrelevant how global poverty is caused or who has caused it. These questions are deemed beside the point, as the utilitarian position espoused by Singer does not recognize any morally relevant difference between harming and refraining from helping. In the end, the utilitarian Singer is concerned with the total sum. Solving the problem of global poverty is therefore simply a matter of adding and subtracting: that which the wealthy nations have in overabundance must be transferred to the poorer nations until the wealthy nations have reached a point where giving more would have (morally significant) negative consequences for themselves. Thus a position as Singer's, which relies on remedial responsibility, can, in contrast to outcome responsibility, account for positive duties of aid in cases where no one is to blame, as, for example, when a country is struck by a tsunami or some other natural disaster. ${ }^{11}$ Those who have the means to help others in need, ought to do so. Conceivably, however, we could still allow for gradations of duty by taking into account specific circumstances and special relations between people(s). For example, we could argue that those people of country $c$, which has been struck by a natural disaster, who are able to help, have a stronger duty to help their compatriots than other people (from different parts of the world) do. Citizens of countries bordering on $c$, as well as those citizens whose country has close historical ties to $c$, might be next in line, as far as the strength of the duty to aid the inhabitants of $c$ is concerned. These gradations of duties do not, however, imply that others - who are neither inhabitants of $c$ nor of a neighboring country nor of a country that has strong historic ties to $c$ - are exempted of all duties to aid the inhabitants of $c$, provided they are able to do so (it would be odd to place a duty on those who themselves are in need of aid).

Positive duties of aid are, however, not limited to cases such as these, where no one is to blame. It may also occur that the poverty of agent $x$ is a consequence of breaches of agent $y$ 's negative duty of forbearance, which however she refuses to remedy. In such a case, the positive duty to aid $x$ might fall to a third party (z) instead. Again, such a duty cannot be accounted for if one relies solely on outcome responsibility (after all, it is not $z$ who is responsible for $x$ 's indigence). Remedial responsibility, by contrast, simply requires agents to help others whenever it is in their power to do so, irrespective of the cause of others' lack, and thus can account for z's duty to help $x$. As in the discussion above of our duties to the inhabitants of the calamity-stricken country $c$, there may be gradations of duty here as well, depending on the relation one has to $x$. 
Both the negative duty of forbearance and the positive duties of aid, discussed above, have relied on what Thomas Pogge has called a traditional, interactionist account of human rights, according to which human rights impose duties on individuals not to harm and duties of aid. The main defect of this position, Pogge maintains, is that it is unable to account for the most important duty regarding subsistence needs, which is institutional in nature. ${ }^{12}$ Our fundamental individual duty corresponding with human rights is, on Pogge's account:

a duty not to contribute to the coercive imposition of any institutional order that avoidably fails to realize human rights, unless one also compensates for one's contribution by working toward appropriate institutional reforms or toward shielding the victims of injustice from the harms one helps produce. ${ }^{13}$

This duty arises from Pogge's institutional approach (which he adopts instead of the interactionist position), which maintains that human rights are in the first place claims on social institutions and in the second place claims on all those who are involved in maintaining such institutions. ${ }^{14}$ Given that the world in which we live constitutes a global institutional order, it follows, furthermore, that the duty here described falls on all persons everywhere, but especially on the more influential and privileged, ${ }^{15}$ because they presumably have contributed to and benefited from this institutional order more than others. The citizens of wealthy nations are thus not simply innocent bystanders, but rather they (knowingly or unknowingly) cooperate in a system that causes and maintains poverty in other parts of the world, to their own advantage. Insofar as we have in this manner caused the harm of others, we are co-responsible for their suffering.

Note that our principal duty regarding others' subsistence needs is a negative duty not to participate in a global system that causes and perpetuates poverty. ${ }^{16}$ It is for this reason, Pogge claims, that his institutional account maintains the middle ground between two extreme positions. ${ }^{17}$ On the one side, minimalist interactional libertarians would argue that we carry no responsibility for violations of rights that we did not cause directly, whereas, on the other side, maximalist interactional utilitarians (such as Singer) hold that we are responsible for all deprivations everywhere as long as we have not given everything we can give, regardless of our causal relation to said deprivations. Pogge maintains the libertarian point that we only have negative duties of justice towards others, without concluding that we therefore have no duties at all towards the global poor. Initially, our duty of justice towards the poor is "merely" to not participate in an institutional order that systematically breaches the right to be free from poverty. Once we have violated this right, however, we acquire "negative-duty-generated positive obligations" ${ }^{\prime 18}$ to actively work for institutional reform and to provide compensation aimed towards poverty alleviation.

The major innovation of Pogge's theory of human rights is its institutional approach. The correlative duties are not limited to avoiding direct harm. Instead, we are under a negative duty to refrain from participating in a harmful system. This duty involves informing oneself about the manner in which the global order operates and the effects it has on people's lives. Pogge cleverly claims that he only recognizes such negative duties of justice: we need merely refrain from harming others, whereby the novelty is that harming must be understood in an institutional and not in an interactional manner. His principle of justice has also been referred to as the "cause principle:" ${ }^{19}$ Pogge holds that we are responsible for global poverty, because and only insofar as we have caused it. The almost libertarian appearance of his position regarding global justice is deceptive, however. For the negative duty to refrain from participating in an unjust order is such that it cannot possibly be fulfilled. Unless one withdraws from society entirely, one will be implicated in the preservation of the unjust order and, consequently, inevitably incur obligations to remedy the harm caused and to help push for reform. Given that the negative duty postulated by Pogge can therefore not be fulfilled (as I will argue 
elaborately in the next section), positive duties were part of his account all along, except for the fact that they now appear in the guise of "voluntarily" incurred obligations.

By merely relying on outcome responsibility, Pogge can thus account not only for the negative duties to refrain from both direct and institutional harm, but also, given that the negative duty of an institutional nature is impossible to fulfill, for positive duties of aid and reform. What he cannot account for, however, given that he relies exclusively on outcome responsibility, are positive duties of aid in situations where either no one at all is responsible or at least I myself am not to blame. ${ }^{20}$

The above brief discussion of Singer and Pogge, whose two accounts of our duties to the global poor have been extremely influential, has uncovered the various duties we have regarding the fulfillment of subsistence needs worldwide. The goal of this section has not been to judge the status of these duties, which will be undertaken next, but rather to provide a complete overview of our individual duties arising from subsistence needs. We may distinguish three separate causes of the nonfulfillment of subsistence needs, which trigger either remedial or outcome responsibility resulting in either negative or positive duties (or both): ${ }^{21}$

1. If poverty is caused by a natural disaster, or some other calamity for which no one is to be blamed, then all who are able to help nonetheless have positive duties of aid. The 'weight' of the duty, however, may depend on specific circumstances and special relations between people(s). This duty relies on our remedial responsibilities.

2. If the cause of poverty is some directly harmful action (e.g. the burning of agricultural lands by an invading army), then (a) the agent who committed this direct harm has a positive duty to remedy (and, of course, a negative duty to refrain from further harming). Here we can rely on outcome responsibility. If that agent refuses or is unable to remedy the situation, we might (b) pass the positive duties of aid on to other, capable agents, in which case we would rely on remedial responsibility. In this case as well (as with duty 1), we allow for the possibility of different gradations of duties, depending on the specific circumstances and the special relations between people and countries.

3. In the case of unfulfilled subsistence needs as a consequence of an unjust (global) politicoeconomic order, we have a negative duty to refrain from participating in that order as well as positive obligations of direct aid and reform if we are unable to fulfill our negative duty. These duties are allocated by relying solely on outcome responsibility.

This results in the following schema of all our possible individual duties concerning the fulfillment of subsistence needs:

\begin{tabular}{|l|l|l|l|}
\hline Cause of poverty & Who has duties? & What duties? & $\begin{array}{l}\text { Basis for } \\
\text { according duties }\end{array}$ \\
\hline $\begin{array}{l}\text { 1. Natural disaster } \\
\text { (no one is to blame) }\end{array}$ & $\begin{array}{l}\text { All, but gradations of } \\
\text { duty and ability to } \\
\text { help are taken into } \\
\text { account }\end{array}$ & Positive duties of aid & $\begin{array}{l}\text { Remedial } \\
\text { responsibility }\end{array}$ \\
\hline 2. Direct harm & $\begin{array}{l}\text { a. The agent that has } \\
\text { harmed }\end{array}$ & $\begin{array}{l}\text { a. Negative duties to } \\
\text { refrain from harming } \\
\text { and positive duties to } \\
\text { remedy }\end{array}$ & $\begin{array}{l}\text { a. Outcome } \\
\text { responsibility }\end{array}$ \\
\hline
\end{tabular}




\begin{tabular}{|l|l|l|l|}
\hline & $\begin{array}{l}\text { b. All, but gradations } \\
\text { of duty and ability to } \\
\text { help are taken into } \\
\text { account }\end{array}$ & $\begin{array}{l}\text { aid } \\
\text { acositive duties of }\end{array}$ & $\begin{array}{l}\text { b. Remedial } \\
\text { responsibility }\end{array}$ \\
\hline $\begin{array}{l}\text { 3. (Global) } \\
\text { institutional harm }\end{array}$ & $\begin{array}{l}\text { All those } \\
\text { participating in the } \\
\text { institutional scheme }\end{array}$ & $\begin{array}{l}\text { Negative duty to } \\
\text { refrain from } \\
\text { participating in unjust } \\
\text { schemes. Otherwise, } \\
\text { positive duties to } \\
\text { remedy and reform } \\
\text { are incurred }\end{array}$ & $\begin{array}{l}\text { Outcome } \\
\text { responsibility }\end{array}$ \\
\hline
\end{tabular}

Figure 1

What this overview does not show, however, is the status of these duties. The question whether such duties are perfect or imperfect, duties of justice or duties of virtue, will therefore be treated next.

\section{What is the status of our duties concerning the fulfillment of subsistence needs?}

This section will separately discuss each of the duties in the schema provided at the end of the previous section in order to ascertain the status of our duties as individuals to the global poor. First, however, we must provide adequate definitions of the relevant terms that are subsequently to be applied to the duties listed in figure 1. Accordingly, this section will commence by clarifying the distinction between perfect and imperfect duties as well as the division between duties of justice and duties of virtue.

Over two thousand years ago Cicero briefly summarized the problem of our duties to the needy by observing that "the resources of the individual are limited, whereas there is a numberless crowd of those in need of them." 22 Throughout the history of practical philosophy such thoughts have led to the conclusion that our duties to the needy are greatly underdetermined (and potentially overdemanding). Kant would argue that the lack of determinacy stems from the fact that our duties to the needy do not prescribe particular actions, but rather specific maxims for action. There is therefore a certain measure of latitude (Spielraum) concerning the manner of their fulfillment: ${ }^{23}$ how one should act, as well as how much one is to do for whom, is not precisely determined. These matters are therefore largely at the agent's discretion. It follows, according to this train of thought, that duties of aid are imperfect.

Our current understanding of the perfect-imperfect distinction finds it origin in the work of the $17^{\text {th }}$ century Dutch jurist and legal philosopher Hugo Grotius, ${ }^{24}$ as does the habit of connecting perfect rights and duties to justice and imperfect rights and duties to virtue. Thus, according to Grotius, rights that may be enforced, and the violation of which constitutes a wrong, are perfect in nature, whereas imperfect rights may not be enforced, nor is anyone wronged by their violation. ${ }^{25}$ Having some moral reason to see a duty performed is therefore not enough to render the duty perfect. Only if we have a perfect right to its performance does its non-fulfillment constitute a violation of justice. Otherwise, the duty in question is imperfect and its fulfillment is a matter not of justice, but virtue ("Liberality, Gratitude, Compassion, or Charity"). ${ }^{26}$ 
The German philosopher Samuel von Pufendorf adopts Grotius's distinction and develops it further. He views perfect rights as those warranting the use of force (i.e. legal action in a civil state or, between States, war) against those who would violate them ${ }^{27}$ By contrast, the performance of imperfect duties, such as "duties of humanity, beneficence, and gratitude," ${ }^{28}$ cannot be extorted by force. The reason why, according to Pufendorf, perfect rights and duties are and ought to be enforceable, is that the performance of perfect duties and the protection of perfect rights are necessary if society is to exist at all. Imperfect rights and duties, on the other hand, contribute only to society's wellbeing. There thus appears to be a hierarchy of duties: society could very well continue to exist without the performance of imperfect duties, whereas perfect duties are paramount to its survival. Given the importance of perfect duties for the very being of society, they ought to be enforceable; no such need, however, pertains to imperfect duties. Finally, Pufendorf maintains that imperfect duties are not as clearly defined as perfect duties; in the case of the provision of goods, for example, imperfect duties do "not consider whether that which is furnished is equal or not to that on account of which something is owed." ${ }^{29}$ In the case of imperfect duties the agent can therefore not rely on clear legal prescriptions, but must instead follow her own "sense of decency and conscience." 30 How much one ought to give, is thus left up to the discretion of the agent. In sum, perfect rights and duties are characterized by enforceability and precision, whereas unenforceability and lack of precision are traits associated rather with imperfect rights and duties. ${ }^{31}$ The former are, moreover, of more fundamental importance for society than the latter.

The contemporary understanding of the perfect-imperfect distinction is roughly the same. The prevalence of the idea that imperfect duties are somehow of lesser importance becomes apparent from the great pains several authors go to in order to prove that subsistence needs do not "merely" give rise to imperfect duties, but should instead be situated within the realm of justice. ${ }^{32}$ Similarly, both the (im)precision component ${ }^{33}$ and the (un)enforceability, or rather the (un)claimability component are to this day common characteristics of the perfect-imperfect distinction: who bears the duty, what the content of the duty is and for whom the duty-bearer must perform it, all this is clearly determined in the case of perfect duties. By contrast, if one of these points remains indeterminate we have to do with an imperfect duty. Thus, when either the duty-bearer has not been identified, the content of the duty has not been specified (leaving the duty-bearer with a measure of latitude concerning the manner in which she will fulfill her duty), or the person for whom the duty must be performed has not been singled out, then the duty in question is imperfect. As a consequence of their determinateness, perfect duties are claimable: the right-holder can identify the duty-bearer(s) and claim the performance of a specific duty from her (or them). In the case of imperfect duties, instead, it is not clear how to pair up right-holders and duty-bearers, nor what the content of the duties is precisely.

In examining the four duties from the schema provided at the end of the previous section, I will mainly attempt to answer the question whether the duty under consideration is a duty of justice or a duty of virtue. Though I do not believe these terms to be strictly synonymous with perfect and imperfect duties ${ }^{34}$ respectively, I will hold that imperfect duties cannot be duties of justice. ${ }^{35} \mathrm{My}$ understanding of duties of justice, furthermore, can be briefly summarized as follows: if there is a right, then there is a duty of justice, the performance of which is owed to the right-holder and the nonfulfillment of which constitutes a wrong. ${ }^{36}$ If, therefore, a duty may be weighed against a different duty, or the agent may freely choose which aspect of the duty to fulfill without committing a wrong, then the duty in question cannot be a duty of justice, but must instead be taken to be a duty of virtue. ${ }^{37}$

With these definitions in mind, let us proceed to examine the status of the duty to refrain from (global) institutional harm. 
Duty to refrain from direct harm

I will start with the least contentious of the duties listed in the schema above, namely the duty to refrain from direct ${ }^{38}$ harm and to remedy the harm caused (duty 2.a). The content of this classic Ulpian duty of neminem laedere ("do not harm anybody") is unambiguous: I ought not to harm anyone. Accordingly, violations are easily detected, rendering this duty enforceable. Requiring merely forbearance, this duty can, furthermore, be easily performed by all for all and is thus universal. We may therefore conclude that this universal, perfect duty is indeed a duty of justice. When, however, this negative duty is violated (say the agent is a member of a rebel group and, as such, takes part in the burning of the farmlands of the rebels' enemies), the duty-bearer incurs positive duties of remedy. Though the content of such duties would need to be specified for each case (depending on the gravity of the offence and, if several agents were involved, one's part in the violation), they are nonetheless duties of justice, as they are incurred as a direct consequence of the violation of the duty of justice to refrain from direct harm. Furthermore, the duty-bearer and the person(s) to whom compensation is owed are clearly identifiable. The precise content of such positive duties of reparation could be specified by a court of law, for example.

This seemingly straightforward duty could, however, be rendered more complicated by arguing that the duty to refrain from harming also includes the duty to exercise one's rights in a responsible manner. In a manner analogous to, say, the right to freedom of expression, ${ }^{39}$ the right to (acquire) property, for example, is limited by the rights of others. If one exercises this right in such a manner that there remains little to nothing left for others, then one has exercised one's right without due respect for the equal rights of others. This Lockean duty ${ }^{40}$ would exclude such practices as land grabbing, i.e. the buying up of enormous swaths of land in developing countries by foreign companies or governments. This example shows how harming by exercising one's right without due respect for the rights of others may also be a perfect duty: no one is permitted to acquire such quantities of land as would endanger the ability of others to fulfill their subsistence needs. This duty requires merely forbearance and can thus easily be performed by all for all; it is therefore universal. The content of the duty is specific enough, though it may, as in the case of the right to freedom of expression, require further fleshing out. As with the right to freedom of expression, whether one has exceeded the limits of one's right to property could be determined case by case by a court of law. In general terms, however, the duty is clear enough to be considered determinate and claimable: everyone has a duty to refrain from acquiring such an amount of property that renders impossible the acquisition of an equitable share by others. Accordingly, the duty to refrain from harming by exercising one's right to property without due respect for the rights of others is a genuine duty of justice.

Duty to refrain from (global) institutional harm

This duty lies at the core of Pogge's account of our duties with regard to the subsistence needs of others. It consists in refraining from participating in unjust orders that foreseeably cause a lack of necessary subsistence goods. By violating this duty, one additionally acquires duties to remedy the harm caused and to push for reform. The negative duty to refrain from institutional harm is the only duty of justice Pogge recognizes (the duties to remedy and reform are in fact obligations incurred only upon violation of one's duty of justice). The reason why, according to Pogge, justice contains solely negative duties, is because, given certain prejudices about negative and positive duties, he believes the former to be more widely accepted because they are viewed as more stringent and less demanding. Pogge claims that his conception of justice is limited in range, as it involves only those "subject to an institutional order you cooperate in imposing." In a globalized world, however, this range could potentially encompass everyone. The range is thus not as limited as he lets on. Furthermore, Pogge maintains that this negative duty (including the two positive obligations) is limited in demandingness as well, since it is 
restricted "to compensation for your share of that part of the human rights deficit that is reasonably avoidable through an alternative institutional design." ${ }^{41}$ It is this supposedly limited demandingness especially that I mean to challenge. ${ }^{42}$

Pogge's insistence that justice contains only negative duties is meant to appease critics of subsistence rights who worry that the correlative duties are overly demanding. Indeed, traditionally, negative duties have been held to have certain advantages over positive duties: they require only forbearance (not positive action), they are universally applicable (all can fulfill them towards all), they are enforceable, and their fulfillment is less costly and thus more compatible with maximal liberty. However, it would seem that this asymmetry between negative and positive duties does not apply when the negative duties are of an institutional nature, as in the case of Pogge. Refraining from harming in a globalized world is not so easy as simply refraining from performing acts most of us would not even consider doing anyway (theft, sexual assault, murder). Instead, to refrain from harming others requires our unending vigilance: Is this T-shirt made by a child in a sweatshop? Are these oranges produced in Israeli settlements in the West Bank? Should I take shorter and less warm showers? Should I eat less meat, because the production of meat is an incredibly inefficient use of farmland? Are my savings being invested in weapons manufacturers by my bank? Are my taxes being used by my government to wage an unjust war? This is just a fraction of the questions we could ask ourselves every day, but this short list of concerns will suffice to show that not harming demands our constant attention. To completely avoid contributing to and benefiting from the global unjust order thus appears to be a Herculean task. It involves informing oneself about the possible consequences of one's behavior - in collaboration with the actions of many other agents - for people in distant lands whom one has most likely never met. The paradigm of harming has thus become very different from the traditional one, whereby one's actions by themselves are sufficient to cause harm without the contribution of others, and the harmful effects of one's actions are immediate and near. ${ }^{43}$ The advantages of negative over positive duties only apply to this classic picture of harming. Pogge, however, abandons this picture and proposes a new, institutional account without wishing to give up the advantages of the classic account (stringency, reasonable demandingness, universality). His theory is thus presented as far less demanding that it is in reality.

Assuming one is able to figure out all the harmful consequences of one's participation in unjust schemes, the question still remains whether or not one can reasonably avoid participating in such a scheme. The language of negative duty conceals the incredibly demanding nature of this command: to absolutely refrain from consuming any products that have been unfairly produced, for example, would already call for a major lifestyle change. But, supposing one's government is involved in upholding unfair trade agreements, one would even be required to move to a different country, lest one contribute to one's government's harmful practices by paying taxes. If one does not succeed in finding a country with a completely innocent government, a real possibility I imagine, one would have to retreat from society altogether to avoid harming others.

Pogge's negative duty to refrain from institutional harm is therefore far more demanding than the classic duty of forbearance. In fact, one could imagine several positive duties of aid less demanding than Pogge's negative duty. Since ought implies can, this negative duty must therefore be viewed as imperfect. ${ }^{44}$ Note that this is "not to be taken as permission to make exceptions to the maxim of actions but only as permission to limit one maxim of duty by another (e.g. love of one's neighbor in general by love of one's parents). ${ }^{45}$ In other words, we do have an imperfect duty to act in light of a certain end i.e. the end of avoiding institutional harm altogether - but the manner in which we fulfill this duty is to an extent at our discretion, and may be limited by other duties.

Pogge's duty to refrain from harming is, furthermore, less precise than it seems. Given that it is not always clear what I ought to do to refrain from harming, the content cannot be said to be 
determinate. Pogge's assertion that we "choose to remain ignorant" ${ }^{26}$ of the manner in which the world economy is structured, what role our government has in shaping it, and what consequences it has for others in the world, is I think a bit too quick. It is difficult, for example, to hold citizens of wealthy nations responsible for the policies developed by the IMF and the World Bank, given that the "IMF is accountable to finance ministers and central bank governors, and its officers are not elected but rather appointed by agreement of governments. ${ }^{\text {47 }}$ Debra Satz further points out that the policy debates of these organizations more often than not take place in secret, rendering it more difficult to obtain information. As long as one is not entirely clear on the policies of these international financial institutions, the content of one's duties to refrain from participating in an unjust order shaped, in part, by these policies, will necessarily remain indeterminate and the duty itself therefore imperfect.

It is difficult to imagine, moreover, how Pogge's negative duty could be claimable. It would involve a specific victim, often in a different country, seeking out one of the many agents who contributed to the preservation of an unjust order that has caused her harm, as responsible for her condition. What justifies her claim on him specifically, when she might have placed her claim on so many possible others (that have likewise participated in the same order)? This question shows that the pairing of victim and violator, and thus claimability, has become problematic, another indication that the duty in question is imperfect.

The positive duties to remedy harm caused and to push for reform face a similar problem. It seems difficult for a particular person in need of assistance to claim aid or reform efforts from a specific duty-bearer. These positive duties, furthermore, are underdetermined in two ways. The first sense in which they are underdetermined concerns the question how much I ought to do. Pogge answers as follows: "The word 'compensate' is meant to indicate that how much one should be willing to contribute toward reforming unjust institutions and toward mitigating the harms they cause depends on how much one is contributing to, and benefiting from, their maintenance." ${ }^{48}$ But how am I to measure how much I have contributed and benefited $?^{49}$ And even if I could provide such an exact figure, how ought I then to translate that into aid and reform efforts? This brings us to the second sense in which Pogge's positive duties are underdetermined: it is unclear whom ought I to help first and how much. Where should the focus of my reform efforts lie?

Given the global range of the harmful institutions in which one has participated, the persons for whom one might provide aid or for whose cause one might lobby and undertake reform efforts, are numerous: one could lobby to overhaul the EU agricultural subsidies, which render it impossible for African farmers to compete and make a living, given the extremely low prices of subsidized European agricultural produce. Yet, one could also provide direct aid to victims of an unjust war in which one's country has participated, or dedicate one's time and effort to any one of the many other cases of subsistence rights violations. Such reform efforts and aid require the seeking out of information about the region in which the problem has occurred, the nature of the problem in question, its causes, and effective ways of helping or reforming. It is possible for an individual to do this for one cause or perhaps two at a time, but certainly not for all the cases in which people suffer from poverty. Duties of aid and reform do not dictate which of these many possible cases I ought to focus on; this is thus a matter of discretion.

Both the negative duty to refrain from upholding harmful institutions and the positive duties resulting from its violation are thus not sufficiently determinate, nor is it clear how right-holders could claim the performance of these duties. As a result, we must conclude that they are imperfect. Indeed, Elizabeth Ashford, whose position is in many ways similar to Pogge's, admits that this is the case: in the absence of just institutions that can allocate and specify the duties, they remain imperfect. ${ }^{50}$ Nonetheless, Ashford maintains, they are (imperfect!) duties of justice. At this point, however, we ought to ask 
ourselves what we mean when we speak of 'duties of justice.' Unfortunately, more often than not this term is employed without the provision of a clear definition. Often it seems that the term 'justice' is simply used in order to convey that something is very important, whereby the possibility that certain duties may be of fundamental importance but are not matters of justice, is rejected out of hand. Indeed, the greater the number of duties that are given the predicate 'duty of justice,' the more all other duties seem to be devalued. Certain liberals even place the duty to treat "each as an end" within the sphere of basic justice, ${ }^{51}$ while Kant, from whom they presumably borrow this duty, clearly did not view this as a matter of justice (or right, Recht), as it fails to fulfill the first condition of right (namely that it regards only the external actions of individuals, insofar as they can affect others).

We will thus need to define duties of justice more precisely. ${ }^{52}$ The common idea that duties of justice are perfect and duties of virtue imperfect has been contested of late. Instead, some scholars have made the argument that the imperfect duties under discussion here are duties of justice that ought to be made perfect. ${ }^{53}$ This duty to develop institutional structures that can define and allocate imperfect duties, rendering them perfect and enforceable, is itself imperfect as well. Nonetheless, this too is held to be a duty of justice. Yet, if it is no longer the perfection of duties that places them within the sphere of justice, what criterion for duties of justice is used instead? A second traditional approach to the distinction, found in the work of Pogge and in the writings of most libertarians, holds that only negative duties can be duties of justice. This theory has also been rejected, however, since the positive duties to aid and reform are considered to be duties of justice as well. Alternatively, a third option would be to make an appeal to the claimability of the duties. Yet, again this suggestion is turned down. After all, these scholars regard duties to reform and aid, as well as duties to not participate in harmful institutions, as duties of justice despite the fact that they are not claimable at present. Finally, duties of justice have often been held to be those duties that have corresponding rights. It is this definition to which these authors appeal: the right to an adequate standard of living exists, because it protects a fundamental human interest. ${ }^{54}$ This right then gives rise to duties that, though they are of an imperfect nature, are nonetheless considered to be duties of justice, precisely because they arise from a right. It is the importance of the right in question, furthermore, which leads to calls for institutionalization so as to render the duties perfect, lest the rights remain unfulfilled:

It is therefore not true that an institutional specification of duties is a condition of the right's existence. The right exists, and imposes corresponding obligations, even in the absence of any institutional allocation of duties. In particular, it imposes $[\ldots]$ the corresponding duty to coordinate with others to bring about an institutional allocation of duties that realizes the right, insofar as this is reasonably possible. $^{55}$

Here it must be clarified, however, how the term 'right' is utilized in this line of argument. Crucially, this understanding of right does not connect having a right to $\mathrm{X}$ with a right to coerce others to provide you with X. After all, prior to institutionalization the latter right does not exist. ${ }^{56}$ Rather, a right to $\mathrm{X}$ seems to give rise to what is referred to as an "imperfect duty of justice" to set up institutions that can make possible such enforcement of the duties to aid and reform.

On the account I have put forward at the beginning of this section, if there is a right, then there is a duty of justice, the performance of which is owed to the right-holder and the non-fulfillment of which wrongs her. A right to subsistence, however - given the impossibility of the negative duty to wholly refrain from participating in unjust institutions - generates duties of aid and reform, which I have argued cannot be performed by all for all. I will thus have to choose whom I will aid and for which cause I will lobby for institutional reform. It seems to me, however, that if I choose to help needy persons $\mathrm{A}$ and $\mathrm{B}$, and, due to human finitude, am not able to help all the others who are equally 
deserving of my help, I do not wrong those that I have not helped. But if we accept this line of argument, then we would also have to accept that there is such a thing as a right, whereby the non-performance of its correlative duty does not constitute a wrong towards the holder of this right. ${ }^{57}$ Yet this is problematic, for normally those duties that one can refrain from performing without wronging anyone are considered to be duties of virtue: "failure to fulfill them [i.e. duties of virtue] is not in itself culpability $($ demeritum $)=-\mathrm{a}$, but rather mere deficiency in moral worth $=0 .{ }^{, 58}$ Therefore it seems, thus far, that the duties correlative to the right to subsistence (as described in the institutional account) are, in fact, duties of virtue.

Still, those who view these imperfect duties as duties of justice could argue that the right to subsistence is in fact not held against particular individuals, but rather "against the vast group of agents who participate in these [unjust] social institutions." 59 The right-holder thus has a right that the wealthy coordinate as a group to fulfill her right. This would do away with the argument based on human finitude, for conceivably if the wealthy would coordinate their relief and reform efforts they would in fact succeed in fulfilling subsistence rights for all. There would be no need for picking and choosing aid recipients (which leads to the suspicion that subsistence rights correlate with duties of virtue, as discussed in the previous paragraph), because as a group they could fulfill the subsistence rights of all. But even if we grant that this is possible, the worry would be that rights held against an amorphous and anonymous group will de facto not be claimable. After all, without institutions the question remains where concretely one's claim can be lodged when one's right has not yet been fulfilled. The answer that the wealthy of the world as a group are responsible does not help us much: "Claimants who do not know who bears the counterpart obligations to rights they claim may grasp thin air." ${ }^{, 60}$ It seems this warning applies to the case of 'group duties' as well. Placing the correlative duty on the shoulders of a collective may conceivably solve the problem of finitude, but it leaves the question "Who should do what for whom?" unanswered. Rights held against groups thus do not provide clear guidelines for individual agency.

Should we then conclude that our individual, institutional duties to the global poor are "merely" duties of virtue? They are, as we have argued, (1) indeterminate: which duty-bearers must perform which duties for which right-holder(s) remains unclear. As a consequence, they are (2) not claimable: if one does not know who owes what to whom, how is one to claim anything? Consequently, the duties to the poor appear to have (3) no correlative rights, since we understand having a right to mean one has a right to coerce another to perform a certain duty. Given these three characteristics it seems we must conclude that our duties concerning global subsistence needs are duties of virtue. ${ }^{61}$

There remains, however, a crucial difference between our individual duties stemming from subsistence needs and traditional duties of virtue: the latter are not typically performed as recompense for an injustice for which one is (co)responsible. Regarding global poverty, however, I believe Pogge can be credited with having convincingly demonstrated that, in fact, we are implicated in this injustice. If we accept this, then it seems unsatisfying to classify these duties as duties of virtue. Yet, judging them to be genuine duties of justice also seems inaccurate (as argued above). If we are to overcome this stalemate, we should recall that, at least according to the account I have provided, duties of justice are limited to those duties that correlate with a corresponding right to coerce. ${ }^{62}$ Given that the duties in question are imperfect and therefore not claimable, it cannot be meaningfully held that these duties give rise to such a right. A human right to subsistence - whereby 'right' must be understood as consisting in the ability to coerce the duty-bearer to perform the correlative duty - thus becomes problematic.

Proponents of this human right will undoubtedly view this as an undesirable conclusion. They could argue that the victims of the unjust global order thus appear to be punished twice: first their subsistence needs remain unfulfilled due to the workings of the unfair global basic structure and 
subsequently we conclude that they are unable to make claims of justice on those participating in and benefiting from that same global order, simply because its complexity renders the pairing of victim and violator extremely difficult. ${ }^{63} \mathrm{I}$ am not insensitive to this criticism. And I by no means conclude that we have no duties to the global poor. Rather, we do have strong duties to aid the global poor and strive for reform, but I argue these duties at present fall outside the scope of justice.

We should be careful not to employ certain words and concepts too easily: if we speak of a human right to subsistence, but the right-holder is unable to claim the performance of the corresponding duty from a specific duty-bearer, then one could wonder about the point of speaking of a right. If we speak of duties of justice, but it is utterly unclear what one ought to do for whom, then the meaning of 'justice' has been altered to a point where it comes suspiciously close to virtue. The term 'duty of justice' should add something that sets it apart from duties of virtue. As argued above however, the structure of the institutional duties stemming from global subsistence needs is too similar to duties of virtue to be able to speak of duties of justice. If a duty is indeterminate and unclaimable it seems misleading to speak of duties of justice. This term creates expectations that, at present, can simply not be fulfilled. ${ }^{64}$

\section{Duties of a Remedial Nature}

Thus far we have dealt with situations in which subsistence rights are unfulfilled as a consequence of either direct or institutional harm. We have found that the duty to refrain from direct harm is a duty of justice, whereas the duty to refrain from institutional harm and the positive duties one incurs upon violation of this duty (i.e. the duties to provide aid and push for reform) are duties of virtue. What remains is to discuss the cases in which the lack of subsistence goods is either no one's fault (duty 1), or at least not my fault (duty 2.b), and remedial duties kick in. We will begin by discussing the former. Consider the plight of a country struck by an environmental disaster (e.g. a volcanic eruption or a tsunami), leaving countless inhabitants without secure access to food and shelter. Let us further stipulate that this environmental disaster did not occur as a consequence of climate change caused by man. In other words, this is not a matter of institutional harming: no one is to blame. At first glance, this situation might perhaps appear analogous to Singer's easy rescue case: we are not responsible for the trouble in which the child in the pond finds himself, but we are in a position to help and the rescue effort will not cost us any great effort or resources. Therefore, Singer concludes we have a duty to save the child. Similarly, the lack of subsistence goods in the afflicted country is not our doing, but if (wealthy) countries work together they could, conceivably, alleviate the country's problems without too great a cost to themselves. This, however, is where the similarities end. In the easy rescue case it is clear who should do what for whom - I, the single passerby, should wade into the pond and save the child - rendering the duty in this example both perfect and possibly a duty of justice. In fact, several countries actually have such Good Samaritan laws, which include a duty to rescue. In the case of a natural disaster, by contrast, there are many possible candidates for the role of the Good Samaritan. Moreover, there could be various countries struck by natural disasters that are in need of our help. ${ }^{65}$ Furthermore, we argued earlier on (in Section I) that the duty to aid others in need (for which no one is to blame) allows for gradations of duty, by taking into account the special circumstances of the dutybearer (is she able to help a lot or only a little, or perhaps not at all?) as well as the special relations between people and nations. The duty to assist in cases of a natural calamity is therefore underdetermined and unclaimable, hence imperfect. We must conclude, consequently, that the duty in question is a duty of virtue.

This is not to say that we do not have strong moral reasons to aid those in need. We indeed have significant duties of virtue to help them. But if we do not help them, or if we help others who are equally in need and deserving of our help, then we do not wrong them. ${ }^{66}$ For only if one has what 
Grotius termed a "perfect right" to the performance of a duty does its non-fulfillment constitute a wrong and thus a violation of justice. Furthermore, the imperfect duty to aid others who, through no one's fault, are in need of help can also become a perfect duty. Within a particular institutional scheme, the indigent can lodge their claim with a specified agency that assumes the duty of aid. All others in the scheme have the duty to cooperate with and contribute to this scheme. Thus when a fellow citizen, for example, has an accident, rendering her disabled and unable to work, the welfare state assumes the duty to ensure she is taken care of and has enough means to live her life. Indirectly, all the citizens share in this duty by complying with the welfare system and by paying taxes. In such a fashion an imperfect duty can be institutionalized and become a duty of justice. Somewhat analogously, countries could resolve to set up an international fund for disaster relief, under the supervision of the UN for instance, which could be relied on in cases of emergencies. In the case, however, where such an institutional structure is missing, individuals' duties to aid are imperfect in nature, and thus duties of virtue.

It is likely that not everyone will agree with this assessment. In National Responsibility and Global Justice, for example, David Miller holds that such remedial duties do fall within the purview of justice, though he does not provide an explicit argument for this position. Even more curious, he argues that such duties "must be discharged as a matter of justice, assuming that the relevant agent or agents are able to do so without infringing other, weightier, duties of justice. ${ }^{97}$ On a Kantian account, however, the "permission to limit one maxim of duty by another" ${ }^{68}$ forms a clear indication that the duties at hand are imperfect and hence not duties of justice. By admitting that there are weightier duties of justice and that precedence ought to be given to such duties in a possible case of conflict, Miller himself in fact already describes the remedial duties to aid others after a (natural) disaster as duties of virtue. His insistence that they are nonetheless duties of justice therefore seems merely stipulative.

Finally, consider the duty (duty 2.b) pertaining to the following situation: a large part of a particular country's GDP has the tendency to end up filling the large pockets of a small group of extremely wealthy and powerful oligarchs, who either reside within the upper echelons of the government or wield considerable influence on the administration's policy through their political clients. As a result, large portions of the people of this country find themselves in need of poverty relief. Obviously, primary responsibility for their indigence lies with the band of oligarchs. They, however, have no intention of leaving their fraudulent ways behind them. The question thus arises whether individuals of the world's wealthy nations have a duty of justice to assist those in need.

In addition to suffering from the same defects as the previously discussed remedial duty - i.e. being underdetermined and unclaimable, hence imperfect - the duties in question are, as it were, 'secondary.' What I mean is that the duty to aid the inhabitants of this country originates in the failure of the primary duty-bearers. We are not to blame for the inhabitants' indigence and our duties to help them do thus not stem from an injustice we have perpetrated against them for which we now owe them recompense. Given that the primary responsibility lies with the small group of oligarchs, Miller is right that the secondary duty-bearers "cannot be required to act." ${ }^{\prime 99}$ Accordingly, the oligarchs' refusal to fulfill their duty of justice to refrain from their harmful, fraudulent activities results in individuals elsewhere incurring not duties of justice, but rather duties of virtue to aid those in need. schema:

By applying the conclusions of this subsection to figure 1, we end up with the following 


\begin{tabular}{|c|c|c|c|c|}
\hline $\begin{array}{l}\text { Cause of } \\
\text { poverty }\end{array}$ & $\begin{array}{l}\text { Who has } \\
\text { duties? }\end{array}$ & What duties? & $\begin{array}{l}\text { Basis for } \\
\text { according } \\
\text { duties }\end{array}$ & $\begin{array}{l}\text { Status of } \\
\text { duties }\end{array}$ \\
\hline $\begin{array}{l}\text { 1. Natural } \\
\text { disaster }\end{array}$ & $\begin{array}{l}\text { All, but } \\
\text { gradations of } \\
\text { duty and ability } \\
\text { to help are taken } \\
\text { into account. }\end{array}$ & $\begin{array}{l}\text { Positive duties } \\
\text { of aid }\end{array}$ & $\begin{array}{l}\text { Remedial } \\
\text { responsibility }\end{array}$ & $\begin{array}{l}\text { Duties of } \\
\text { virtue }^{70}\end{array}$ \\
\hline 2. Direct harm & $\begin{array}{l}\text { a. The agent that } \\
\text { has harmed } \\
\text { b. All, but } \\
\text { gradations of } \\
\text { duty and ability } \\
\text { to help are taken } \\
\text { into account. }\end{array}$ & $\begin{array}{l}\text { a. Negative } \\
\text { duties to refrain } \\
\text { from harming } \\
\text { and positive } \\
\text { duties to remedy } \\
\text { b. Positive } \\
\text { duties of aid }\end{array}$ & $\begin{array}{l}\text { a. Outcome } \\
\text { responsibility } \\
\text { b. Remedial } \\
\text { responsibility }\end{array}$ & $\begin{array}{l}\text { a. Duties of } \\
\text { justice } \\
\text { b. Duties of } \\
\text { virtue }\end{array}$ \\
\hline $\begin{array}{l}\text { 3. (Global) } \\
\text { institutional } \\
\text { harm }\end{array}$ & $\begin{array}{l}\text { All those } \\
\text { participating in } \\
\text { the institutional } \\
\text { scheme }\end{array}$ & $\begin{array}{l}\text { Negative duty to } \\
\text { refrain from } \\
\text { participating in } \\
\text { unjust schemes, } \\
\text { and positive } \\
\text { duties to remedy } \\
\text { and reform }\end{array}$ & $\begin{array}{l}\text { Outcome } \\
\text { responsibility }\end{array}$ & Duties of virtue \\
\hline
\end{tabular}

Figure 2

As this overview shows, we have found that in the absence of institutions to determine and allocate individual duties to the poor, most of these are best understood as duties of virtue. No doubt this result will be considered disappointing by those authors wishing to establish hard duties of justice to alleviate subsistence needs. However, I hope to have shown that if the concept 'justice' is to be a fruitful concept, it ought to be clearly distinct from its partner concept 'virtue.' Accordingly, I have suggested that the realm of justice be limited to those rights and duties that fulfill the conditions of determinacy and claimability. If we were to abandon these prerequisites, then the important distinction between justice and virtue would be rendered obscure, resulting in "duties of justice" that are either indeterminate or unclaimable, or both. What could be the motivation for such an approach? Many authors wish to avoid what they view as the stigma of having the duties stemming from subsistence needs branded as duties of virtue, as they believe these to be of lesser importance than duties of justice. They therefore insist in classifying our duties to the poor as duties of justice in order to emphasize the fact that we truly have very strong reasons to fulfill certain duties to the poor. In doing so, however, they forget that duties of virtue provide us with strong moral reasons for certain courses of action as well. In fact, they are of fundamental importance and serve an indispensable role as complement to (duties of) justice. 


\section{Conclusion}

We started our study of the duties arising from subsistence needs by providing, in Section I, an overview of all the possible individual duties concerning the fulfillment of subsistence needs (see figure 1). We distinguished three separate causes of the non-fulfillment of subsistence needs, which trigger either remedial or outcome responsibility resulting in either negative or positive duties (or both). Subsequently, the need arose to clarify the status of these duties. This task was undertaken in Section II. As a first step, we expounded the difference between perfect and imperfect duties. The conclusion was that perfect duties are determinate (i.e. it is clear who is to do what for whom) and claimable, whereas imperfect duties possess the opposite properties. Following these definitions, the duties springing from subsistence needs were deemed imperfect, save for the duty to refrain from directly depriving others' means of subsistence. We argued, furthermore, that duties of justice are those duties that (can) have corresponding rights to coerce. Duties of virtue, by contrast, do not have such corresponding rights, since they do not specify who may claim what from whom. We therefore concluded that all the duties relative to subsistence needs (save for the duty to refrain from direct harm) are duties of virtue.

This conclusion should lead neither to the belief that therefore our duties to the global poor are not important, nor that these duties of virtue cannot become duties of justice. Regarding the latter point, we could say that our conclusion that under present circumstances these duties are duties of virtue underlines the importance of the creation of institutions and legislation that can specify and allocate duties, perhaps rendering them duties of justice one day. Miller, too, views the creation of certain global institutions that can distribute our sundry duties to fulfill the subsistence needs of the global poor as the only way in which what he terms the "justice gap" can be narrowed, even if it can perhaps not be entirely filled. Indeed, the importance of allocating institutions in general is underwritten by those involved in human rights practice as well. They would argue that a good way to guarantee subsistence rights is by enshrining the right to food, for example, in the country's constitution. ${ }^{72}$ An even better solution, however, is to draft so-called framework legislation ${ }^{73}$ on the right to food. As the UN's Food and Agriculture Organization states:

A framework law on the right to food can give a precise definition of the scope and content of this human right, set out obligations for state authorities and private actors, establish necessary institutional mechanisms and give the legal basis for subsidiary legislation and other necessary measures to be taken by the competent state authorities. ${ }^{74}$

The necessity to render duties perfect by implementing national or international legislation is thus clearly recognized. The hope is that by embedding subsistence rights, such as the right to food, within an institutional and legal setting, its fulfillment will be guaranteed.

No institutional scheme or set of laws is perfect, however. There will always be cases that slip through the cracks. Even institutional schemes that are largely just and generally complied with will not be able to completely prevent cases of unfulfilled rights. It is here that the importance of duties of virtue lies: when there are no institutions to allocate duties and ensure their performance (as is the case, I have argued, with our current duties to the global poor), or such institutions do not function flawlessly (which will, most likely, always be the case), duties of virtue function as a necessary and indispensable complement to the sphere of justice. Our duties of virtue include, among others, duties to help those who, as said, slip through the cracks and duties to push for reform of the prevailing institutions so that fewer cracks remain. 
The creation of and compliance with just institutions, i.e. justice, is not enough. It is, to say the least, doubtable that the liberal dream of just institutions without virtuous people, can be realized. Virtue therefore remains necessary. Contrary to common opinion, therefore, our conclusion that (most of) our individual duties to the global poor are duties of virtue is by no means meant to derogate anything from their importance. Rather, it can be viewed as a reassertion of the value of (duties of) virtue.

Endnotes

${ }^{1}$ CESCR. General Comment No. 12: The Right to Adequate Food (Art. 11). E/C.12/1999/5 (12 May 1999). Paras. 40-1. Paragraph 40 discusses the role of NGO's, whereas paragraph 41 contains a number of recommendations for international financial institutions with regard to securing the right to food; cf. CESCR. General Comment No. 14: The Right to the Highest Attainable Standard of Health (Art. 12). E/C.12/2000/4 (11 August 2000). Paras. 63-5.

${ }^{2}$ CESCR. General Comment No. 12. Supra note 1. Para. 20.

${ }^{3}$ When individual duties are mentioned, the CESCR suddenly uses the word "responsibility," whereas it always uses the word "obligation" to refer to the duties of States. Wherein the difference between "responsibility" and "obligation" precisely consists, however, is left unsaid, as is the reason for attributing the one term to States and the other to individuals.

${ }^{4}$ Following authors like Hart and Rawls, I argue it makes sense to distinguish here between duties and obligations. Both the mentioned authors argue that we mostly speak of 'obligations' when they are voluntarily incurred, that is, when they are a consequence of our actions (see Rawls, J. (1999). Legal Obligation and the Duty of Fair Play. In S. Freeman (Ed.), Collected Papers (pp. 117-129). Cambridge, MA: Harvard University Press. 118; also see Hart, H. L. A. (1955). Are There Any Natural Rights? The Philosophical Review, 64(2), 175-191. 179n). Conversely, 'duties' are held prior to and irrespective of the agent's behavior. For the majority of this article, however, I will use the terms 'positive duties' and 'positive obligations' interchangeably, except when for reasons of clarity it becomes necessary to emphasize the difference (between duties and obligations).

${ }^{5}$ Miller, D. (2007). National Responsibility and Global Justice. Oxford: Oxford University Press. 231.

${ }^{6}$ Ibid.

${ }^{7}$ Singer, P. (1972). Famine, Affluence, and Morality. Philosophy and Public Affairs, 1(3), 229-243. 231.

${ }^{8}$ Ibid. 241.

${ }^{9}$ Ibid.

${ }^{10}$ Ibid. 238.

${ }^{11}$ One could make the argument that natural disasters occur more frequently due to climate change or that their impact is magnified by a faulty warning system or by a government that is unable or unwilling to provide sufficient emergency aid. Though there are certainly situations where this is the case, occasions remain whereby acute need is not the result of anyone's fault and whereby, therefore, no appeal can be made to outcome responsibility.

${ }^{12}$ It is not my intention to defend Pogge's rejection of the interactionist approach, but merely to present an additional individual duty relative to subsistence needs. I merely mention here that a number of authors have argued that the institutional duty Pogge presents is in fact perfectly compatible with the traditional, interactionist approach. See, for example: Stemplowska, Z. (2009). On the Real World Duties Imposed on Us by Human Rights. Journal of Social Philosophy, 40(4), 466-487.

${ }^{13}$ Pogge, T. (2002). Human Rights and Human Responsibilities. In P. De Greiff \& C.P. Cronin (Eds.), Global Justice and Transnational Politics (pp. 151-195). Cambridge, MA: The MIT Press. 166; cf. Pogge, T. (2008). World Poverty and Human Rights: Cosmopolitan Responsibilities and Reforms (Second.). Cambridge: Polity Press. 73. 
${ }^{14}$ Pogge. World Poverty and Human Rights. Supra note 13. 50-1.

${ }^{15}$ Pogge. Human Rights and Human Responsibilities. Supra note 13. 166.

${ }^{16}$ It becomes clear here that Pogge bases his institutional account of human rights on a particular reading of Article 28 UDHR, which views this article as the key for the manner in which we ought to understand all rights listed in this document. Accordingly, Pogge explicitly refers to this article when he argues that the justice of "any institutional order depends primarily on its success in affording all its participants secure access to the objects of their human rights" (Pogge. Human Rights and Human Responsibilities. Supra note 13. 165).

${ }^{17}$ Pogge. World Poverty and Human Rights. Supra note 13. 72.

${ }^{18}$ Pogge, T. (2005). Reply to the Critics: Severe Poverty as a Violation of Negative Duties. Ethics and International Affairs, 19(1), 55-83. 69: "These positive obligations are generated by a negative duty that is correlative to human rights. Failure to fulfill such positive obligations therefore violates human rights." Pogge appears to be using the term 'obligation' in a similar manner as Rawls and Hart (see note 4).

${ }^{19}$ Kreide, R. (2007). Neglected Injustice: Poverty as a Violation of Social Autonomy. In T. Pogge (Ed.), Freedom From Poverty as a Human Right: Who Owes What to the Very Poor? (pp. 155-181). Oxford: Oxford University Press. 172.

${ }^{20}$ Indeed, this is a very common critique of Pogge's work. See, for example: Gilabert, P. (2005). The Duty to Eradicate Global Poverty: Positive or Negative? Ethical Theory and Moral Practice, 7, 537-550. 538; Kreide. Neglected Injustice. Supra note 19. 174-5. Stemplowska. Real World Duties. Supra note 12. 479.

${ }^{21}$ In drawing up this overview I am indebted to David Miller's work: Miller. National Responsibility and Global Justice. Supra note 5. 249-59. One of the main differences between his account and mine, however, resides in the fact that Miller's agents are societies or States, whereas my focus is on individuals and their duties.

${ }^{22}$ Cicero. (2001). On Obligations. (P. G. Walsh, Trans.). Oxford: Oxford University Press. I 52.

${ }^{23}$ Kant, I. (1996). The Metaphysics of Morals. In M. Gregor (Ed. \& Trans.), Practical Philosophy. Cambridge: Cambridge University Press. Ak 6:390 (I refer to the standard Academy pagination of Kant's works).

${ }^{24}$ Schneewind, J.B. (1998). The Invention of Autonomy: A History of Modern Moral Philosophy. Cambridge: Cambridge University Press. 78.

${ }^{25}$ Grotius, H. (2005). The Rights of War and Peace. (J. Barbeyrac, Trans, R. Tuck, Ed.). Indianapolis: Liberty Fund. I.I.iv; cf. II.XII.ix.2.

${ }^{26}$ Ibid. II.XXII.xvi.

${ }^{27}$ Pufendorf, S. (1994). On the Law of Nature and of Nations in Eight Books. In C.L. Car (Ed.), M.J. Seidler (Trans.), The Political Writings of Samuel Pufendorf (pp. 93-268). Oxford: Oxford University Press. I.i.19.

${ }^{28}$ Ibid. I. vii. 15.

${ }^{29}$ Ibid. I. vii. 8 .

${ }^{30}$ Ibid. I. vii. 7.

${ }^{31}$ Schneewind. The Invention of Autonomy. Supra note 24.

${ }^{32}$ See, for example Ashford, E. (2006). The Inadequacy of our Traditional Conception of the Duties Imposed by Human Rights. Canadian Journal of Law and Jurisprudence, XIX(2), 217-235. 219-20; Gilabert, P. (2010). Kant and the Claims of the Poor. Philosophy and Phenomenological Research, 81(2), 382-418. 394ff. In the conclusion of this article I will briefly argue against this common view that imperfect duties are of lesser importance than perfect duties.

${ }^{33}$ E.g. Tan, K. C. (2004). Justice Without Borders: Cosmopolitanism, Nationalism and Patriotism. Cambridge: Cambridge University Press. 50: In the case of perfect duties "who the agent is, what her exact responsibility is, and to whom she owes this responsibility are clearly defined." By contrast, duties are 
imperfect "when no particular agent has been identified, when there is considerable latitude on how an agent may discharge the obligation, and when it is unspecified for whom the act is to be performed."

${ }^{34}$ The duty not to lie, for example, appears to be a perfect duty of virtue.

${ }^{35}$ That this is a contentious view nowadays is confirmed by the works of Ashford and Stemplowska, both of whom argue for the possibility of enforceable imperfect duties, or imperfect duties of justice: Ashford. The Inadequacy of our Traditional Conception. Supra note 32. 234; Stemplowska. Real World Duties. Supra note 12. 482.

${ }^{36}$ I find Joel Feinberg's distinction between 'harming,' understood as causing a setback to another's interests, and 'wronging,' understood as a "violation of one's rights, or an injustice," quite helpful (Feinberg, J. (1984). The Moral Limits of the Criminal Law. Volume One: Harm to Others. New York: Oxford University Press. 107). When I employ the noun 'wrong' (or the verb 'to wrong') I similarly intend a violation of rights.

${ }^{37}$ Certain authors, such as Iris Marion Young, have introduced the seemingly new concept of 'responsibility,' which is thought to be a helpful addition to the traditional duties of justice-duties of virtue dichotomy. However, she describes 'responsibility' in a manner very similar (not to say identical) to the common understanding of duties of virtue: responsibility, as opposed to duties (on Young's account), "is more open as to what action it calls for." One, furthermore, "has the responsibility to do whatever it takes to bring about specific ends or purposes" (my emphasis). Lastly, she explains that taking responsibility involves the exercise of discretion: "It is up to the agents who have a responsibility to decide what to do to discharge it within the limits of other moral considerations" (Young, I. M. (2013). Responsibility for Justice. New York: Oxford University Press. 143). Yet, all the characteristics she mentions - acting in light of ends, exercising discretion, taking into account other moral commitments - are typical of duties of virtue. It seems, therefore, that the necessity for the introduction of the term 'responsibility' arises only as a consequence of the unwarranted conflation of the concept of duty as such (or in general) and duties of justice, thus ignoring the existence of duties of virtue. I therefore leave the concept 'responsibility' aside for the remainder of this text.

${ }^{38}$ Note that we are here speaking only of the duty to refrain from direct harm. The more difficult case of institutional harm will be considered next.

${ }^{39}$ Article 10 of the European Convention on Human Rights guarantees the right to freedom of expression. Section 2 of this article, however, places clear limits on this right: "The exercise of these freedoms, since it carries with it duties and responsibilities, may be subject to such formalities, conditions, restrictions or penalties as are prescribed by law and are necessary in a democratic society, in the interests of national security, territorial integrity or public safety, for the prevention of disorder or crime, for the protection of health or morals, for the protection of the reputation or rights of others, for preventing the disclosure of information received in confidence, or for maintaining the authority and impartiality of the judiciary." The International Covenant on Civil and Political Rights contains a similar socalled 'clawback clause' in Article 19(3).

${ }^{40}$ John Locke argues that one's right to property ought to be exercised in such a manner that does not render impossible the acquisition of a similar amount of property by anyone else: "Labour being the unquestionable Property of the Labourer, no Man but he can have a right to what that is once joyned to, at least where there is enough, and as good left in common for others" (Locke, J. (1988). Two Treatises of Government. (P. Laslett, Ed.). Cambridge: Cambridge University Press. 288). He recognizes a further, more famous limitation on property as well. Everyone may acquire as much property "as any one can make use of to any advantage of life before it spoils; so much he may by his labour fix a Property in. Whatever is beyond this, is more than his share, and belongs to others" (ibid. 290). Locke sets this limit as he is convinced that "[n]othing was made by God for Man to spoil or destroy" (ibid.).

${ }^{41}$ Pogge. Reply to the Critics. Supra note 18. 61.

${ }^{42}$ Other scholars have criticized Pogge on this score as well. See for example Mieth, C. (2008). World Poverty as a Problem of Justice? A Critical Comparison of Three Approaches. Ethical Theory and Moral 
Practice, 11(1), 15-36. 25. Though not directed solely at Pogge, Judith Lichtenberg argues that "ceasing to engage in these 'New Harms' is not at all easy" (Lichtenberg, J. (2010). Negative Duties, Positive Duties, and the 'New Harms.' Ethics, 120(3), 557-578. 558).

${ }^{43}$ Lichtenberg. Negative Duties, Positive Duties, and the 'New Harms.' Supra note 42. 561.

${ }^{44}$ In these pages I mention the problem of demandingness several times. It must be noted, however, that my aim in doing so is not to engage in the discussion of how demanding our moral duties in general (understood as comprising both duties of justice and duties of virtue) may be. Rather, my aim is to point out the problem of overdemandingness for a particular set of individual duties, namely duties of justice, which I take to be perfect duties. The problem of overdemandingness for such perfect duties is as follows: I have listed indeterminacy as a characteristic of imperfect duties. If a duty is so demanding that one cannot completely fulfill it, then one must choose which aspects of the duty one will perform. Pogge's negative, institutional duty, under discussion here, fits this description: it is too demanding to be fulfilled completely. We must therefore make choices: I will refrain, for example, from buying clothing that is produced in sweatshops, but I will not move to another country to avoid paying taxes, which my government uses to participate in an unjust war. Which aspects of this duty one chooses to perform, however, is at the agent's discretion. For this reason, overdemanding duties are imperfect and should therefore not be understood to be duties of justice. If we would consider overdemanding duties to be duties of justice, then we would have to accept a rather skewed concept of a duty of justice. For, habitually, a duty of justice is viewed as a duty, to the performance of which certain right-holders may constrain certain duty-bearers. If we accept that overdemanding duties may also be duties of justice, then we have to accept the idea of a duty of justice, of which certain aspects may be left unfulfilled at the duty-bearers' discretion - a duty of justice, in other words, that may not be completely claimed by the relevant right-holders. In what sense would such a duty still be a duty of justice?

${ }^{45}$ Kant. The Metaphysics of Morals. Supra note 23. Ak 6:390. In this passage Kant actually speaks of 'wide duties.' This term, however, is largely synonymous with 'imperfect duties.'

${ }^{46}$ Pogge. Reply to the Critics. Supra note 18. 79.

${ }^{47}$ Satz, D. (2005). What Do We Owe the Global Poor? Ethics and International Affairs, 19(1), 47-54. $51-2$.

${ }^{48}$ Pogge. World Poverty and Human Rights. Supra note 13. 56.

${ }^{49}$ A related problem, though of a more epistemic nature, is raised by O'Neill who argues that "the causal links between specific individuals or institutions who injured and were injured [...] are too often not clear enough to allocate rights of compensation (O’Neill, O. (2000). Transnational Economic Justice. In Bounds of Justice (pp. 115-142). Cambridge: Cambridge University Press. 132). Also see Satz. What Do We Owe the Global Poor? Supra note 47. 50.

${ }^{50}$ Ashford. The Inadequacy of our Traditional Conception. Supra note 32. 234.

${ }^{51}$ See e.g. Nussbaum, M. (2006). Frontiers of Justice: Disability, Nationality, Species Membership. Cambridge (Mass.): Belknap Press of Harvard University Press. 70.

${ }^{52}$ I am indebted to Allen Buchanan for the four different distinctions between duties of justice and duties of virtue I discuss here: Buchanan, A. (1987). Justice and Virtue. Ethics, 97(3), 558-575. Buchanan, however, employs the terms 'charity' where I speak of 'virtue.'

${ }^{53}$ Gilabert. Kant and the Claims of the Poor. Supra note 32. 399. Ashford. The Inadequacy of our Traditional Conception. Supra note 32. 234.

${ }^{54}$ This position is also known as the interest theory of human rights, an exemplary account of which can be found in the work of Joseph Raz: " $X$ has a right' if and only if [...] an aspect of X's well-being (his interest) is a sufficient reason for holding some other person(s) to be under a duty" (Raz, J. (1986). The Morality of Freedom. Oxford: Oxford University Press. 166).

${ }^{55}$ Ashford, E. (2007). The Duties Imposed by the Human Right to Basic Necessities. In T. Pogge (Ed.), Freedom from Poverty as a Human Right (pp. 183-218). Oxford: Oxford University Press. 216-7. 
56 Though certain authors have attempted to view imperfect rights as claimable prior to institutionalization: cf. Stemplowska. Real World Duties. Supra note 12. 482. Yet, it is not clear how she expects to achieve true claimability on her account, which suggests that all indigents could simply have a claim to help from all those who have not yet undertaken sufficient steps to fulfill their duty.

${ }^{57}$ Notice how different this is from the duty to refrain from torture, for example. Here, if I do not fulfill my duty towards everyone, I most certainly do wrong others.

${ }^{58}$ Kant. The Metaphysics of Morals. Supra note 23. Ak 6:390.

${ }^{59}$ Ashford. The Duties Imposed by the Human Right to Basic Necessities. Supra note 55. 216.

${ }^{60}$ O'Neill, O. (1996). Towards Justice and Virtue: A Constructive Account of Practical Reasoning. Cambridge: Cambridge University Press. 135.

${ }^{61}$ Note that I leave out the fourth characteristic of duties of virtue mentioned above, namely that they are positive (whereas supposedly duties of justice can be only negative). I omit this point, because I hold that justice could also, given the adequate institutions, contain positive duties.

${ }^{62}$ Kant. The Metaphysics of Morals. Supra note 23. Ak 6:383.

${ }^{63}$ I thank an anonymous reviewer for pressing me on this point.

${ }^{64}$ This is not to say that duties of aid, for example, could not become perfect duties of justice in a particular social scheme, such as a welfare state. In such a scheme individuals have clear duties of justice (to comply with the welfare system, to pay taxes) and right-holders have a justiciable right to subsistence goods.

${ }^{65}$ Much in Singer's account hinges on the analogy between the easy rescue case and the problem of global poverty. I have here raised one aspect of the problem of global poverty that renders that analogy problematic. Miller raises two further points against this analogy. Firstly, saving the drowning child is, most likely, a onetime event and will, for this reason, not interfere with our life plans in any significant way. Poverty, on the other hand, is a chronic problem. Secondly, in the easy rescue case the question who has caused the child's troubles is not raised (the child in the pond is simply an innocent victim), whereas in the case of global poverty it is of both moral and practical importance who is found responsible. Otherwise we will not be able to hold those accountable who have contributed to the poverty of others, nor will we obtain any insight into the question how we can prevent prospective breaches of this right (Miller. National Responsibility and Global Justice. Supra note 5. 234-7).

${ }^{66}$ Though if we help no one at all we would be in violation of our duty of virtue.

${ }^{67}$ Miller. National Responsibility and Global Justice. Supra note 5. 255.

${ }^{68}$ Kant. The Metaphysics of Morals. Supra note 23. Ak 6:390.

${ }^{69}$ Miller. National Responsibility and Global Justice. Supra note 5. 258.

${ }^{70}$ It must be noted that those duties that are judged to be duties of virtue in this overview are deemed so due to the absence of an institutional scheme that could allocate the duties in question. For example, all nations could conceivably contribute to an emergency fund, managed by the UN, to which funds they would have a right when disaster strikes their country. In this case all countries that commit to such a scheme would have a duty of justice to contribute to it. Similarly, the institutional duties in this schema could become duties of justice if, for example, there would be a global institution to allocate the duties of each. In the absence of such an institution, however, we must conclude that the duties in question are duties of virtue.

${ }^{71}$ The justice gap is the "gap between what people in poor countries can legitimately claim as a matter of justice $[\ldots]$ and what the citizens of rich countries are obliged, as a matter of justice, to sacrifice to fulfil these claims" (Miller. National Responsibility and Global Justice. Supra note 5. 274).

${ }^{72}$ The right to food is present in the constitutions of South Africa (Article 27(1)), Kenya (Article 43(1)) and Brazil (Article 7(IV)), among others.

${ }^{73}$ Framework legislation lays down rather general principles and duties concerning, in this case, the right to food, which can subsequently be further defined by additional legislation issued by the relevant (national or international) authorities. 
${ }^{74}$ Bojic Bultrini, D. (2009). Guide on Legislating for the Right to Food. Rome: Food and Agriculture Organization of the United Nations. 4. Cf. De Schutter, O. (2010). Countries Tackling Hunger with a Right to Food Approach: Briefing note 1. UN Special Rapporteur on the Right to Food. 13: "National parliaments should be encouraged to work towards the adoption of framework laws that establish a participatory mechanism aimed at the adoption of a national strategy for the realization of the right to food.” 